\title{
o6-Kıpçak Türkçesinde yer alan orman, dağ, tepe kavram alanlarına ait coğrafi terimler
}

\section{Selma ÖZEN ALLI'}

APA: Özen Allı, S. (2020). Kıpçak Türkçesinde yer alan orman, dağ, tepe kavram alanlarına ait coğrafi terimler RumeliDE Dil ve Edebiyat Araştırmaları Dergisi, (Ö8), 87-96. DOI: 10.29000/rumelide.825929.

\section{$\ddot{\mathbf{O} z}$}

Kıpçak Türkçesi, XIII. yüzyıldan ile XVI. yüzyıla kadar Güney Rusya steplerinden, Orta Doğu coğrafyasına kadar uzanan bir sahada varlığını sürdürmüş olan tarihî Türk lehçelerinden biridir. Çeşitli kavram alanlarına ait zengin bir söz varlığı barındıran bu dönem eserlerinde, Türk kültürüne ait pek çok sosyal, iktisadî, etnolojik, folklorik, coğrafî unsur yer alır. Bu çalışmada Kıpçak Türkçesiyle yazılmış eserlerden hareketle orman, dağ, tepe kavram alanlarına ait coğrafya terimlerinin incelenmesi amaçlanmıştır. Çalışma kapsamında öncelikle Prof. Dr.Recep Toparlı, Yrd. Doç Dr. Hanifi Vural ve Yrd. Doç. Dr.Recep Karaatlı'nın hazırlamış olduğu Kıpçak Türkçesi Sözlüğü adlı eserden bu kavram alanlarına ait coğrafya terimleri taranmış ve bu tarama sonucunda tespit edilen terimler orman kavram alanına giren coğrafya terimleri, dağ kavram alanına giren coğrafya terimleri ve tepe kavram alanına giren coğrafya terimleri olmak üzere üç grupta incelenmiştir. Bu terimler, eserdeki anlamları ile ve varsa ek bilgiler ile birlikte verilmiştir. Ardından ilgili terimler etimolojik olarak incelenmiş ve bunların tarihî süreç içindeki durumları ortaya konmaya çalışılmıştır. Son olarak, ele alınan bu terimlerin Türkiye Türkçesindeki kullanımlarına yer verilmiştir. Çalışmanın inceleme kısmında yer alan coğrafya terimlerinin etimolojik açıklamaları başta Clauson'un eseri olan An Etymological Dictionary of Pre-Thirteenth-Century Turkish adlı sözlükten olmak üzere Marttı Rasanen'e ait Versuch Eines Etymologıschen Wörterbuchs Der Türksprachen adlı sözlük ve V.M.Nadalyaev, D.M. Nasilov, E.P.Tenişev, A.M.Şerbak birlikteliğinde hazırlanan Drevnetyurskiy Slovar adlı sözlük kullanılarak yapılmıştır. Bunların yanı sıra Andreas Tietze'nin Tarihî ve Etimolojik Türkiye Türkçesi Lugati ile Hasan Eren'e ait olan Türk Dilinin Etimolojik Sözlüğü ve Tuncer Gülensoy'un yazmış olduğu Türkiye Türkçesindeki Türkçe Sözcüklerin Köken Bilgisi Sözlüğü adlı eserlerden de yararlanılmıştır.

Anahtar kelimeler: Kıpçak Türkçesi, coğrafya terimleri, söz varlığı, etimoloji

\section{Geographical terms regarding the concept areas of forest, mountain, hill in Kipchak Turkish}

\begin{abstract}
Kipchak Turkish, XIII. From the century to the XVI. It is one of the historical Turkish dialects that existed in an area extending from the South Russian steppes to the Middle East geography. In this period's works, which contain a rich vocabulary belonging to various concept areas, there are many social, economic, ethnological, folkloric and geographic elements belonging to Turkish culture. In this study, it is aimed to examine the geography terms belonging to the concept areas of forest, mountain, hill with reference to the works written in Kipchak Turkish. Within the scope of the
\end{abstract}

Öğr. Gör., Zonguldak Bülent Ecevit Üniversitesi, Rektörlük Türk Dili Bölümü (Zonguldak, Türkiye), selmaozen@hotmail.com ORCID ID: oooo-0001-7587-160X [Makale kayit tarihi: 12.09.2020-kabul tarihi: 20.11.2020; DOI: 10.2900o/rumelide.825929]

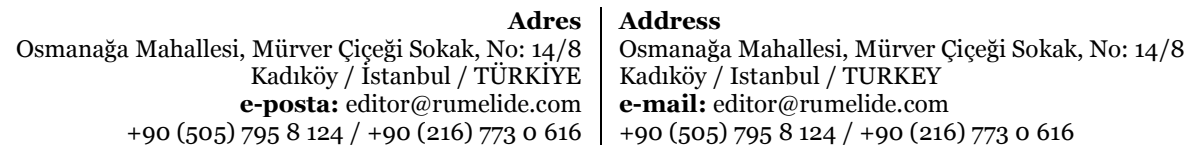


study, Prof. Dr. Recep Paketli, Asst. Associate Professor. Hanifi Vural and Asst. Assoc. Geography terms belonging to these concept areas were scanned from the work named Kipchak Turkish Dictionary prepared by Dr. Recep Karaatlı and the terms determined as a result of this search were divided into three terms: geography terms included in the forest concept field, geography terms included in the field of mountain concept and geography terms included in the field of hill concept. It was examined in the group. These terms are given with their meanings in the work and additional information, if any. Then, the related terms were examined etymologically and their situation in the historical process was tried to be revealed. Finally, given the use of these terms are discussed in Turkey Turkish. The etymological explanations of the geography terms in the review part of the study are mainly from Clauson's An Etymological Dictionary of Pre-Thirteenth-Century Turkish, Versuch Eines Etymologischen Wörterbuchs Der Türksprachen and V.M.Nadalyaev, D.M. Nasilov, E.P.Tenişev, A.M. Şerbak together with Drevnetyurskiy Slovar. These as well as Andreas Tietze Historical and etymological Turkey belonging to Eren Hasan Turkish Lûgat Turkish etymological dictionary of the language, and he wrote Tuncer Gülensoy Turkey's Origin of Turkish words in Turkish Information has benefited from the works called Glossary.

Keywords: Kipchak Turkish, geography terms, vocabulary, etymology.

\section{Giriș}

On üçüncü yüzyıla kadar tek bir koldan ilerleyen Türk dili, Oğuz ve Kıpçak boylarının batıya doğru göç etmeleriyle farklı coğrafyalara yayılmaya başlamıştır. Bu iki Türk kavminden Oğuzlar güneye doğru göç ederken Kıpçaklar da kuzeye göç etmişler ve yerleştikleri yeni coğrafyalarda dilleri birbirinden ayrılarak iki ayrı Türk lehçesi olarak gelişmiştir (Argunşah-Yüksekkaya-Tabaklar 2010: 175). Kıpçak Türkçesi bir taraftan Güney Rusya'da, Kırım'da ve Orta Asya’nın batı bölgelerinde yaşayan göçebe Kıpçak Türklerinin dili iken diğer tarafta Mısır ve Suriye'deki Memluk Devleti’nin Türkçe konuşan yönetici sınıfı ile Ukrayna'da yaşayan Türkleşmiş Ermeniler tarafından da konuşulmuştur. Başka bir deyişle, XIII.-XVII. yüzyıl Kıpçakçasının üç ayrı diyalekti vardır (Tekin-Ölmez 1999: 41). Bu üç farklı diyalekt arasında bazı fonetik ve biçimsel farklılıklar bulunmakla birlikte Aşă̆ı Volga bölgesinde yaşayan Fransiskan misyonerlerinin yazmış olduğu Codex Cumanicus adlı eser ile Kırım’a yerleşerek Kıpçaklarla olan yakın ilişkileri sonunda Kıpçak Türkçesini benimseyen Ermenilerin tuttukları kayıt ve resmi belgelerden oluşan Ermeni Kıpçakçası metinleri Hristiyan dinine ait öğeler içermesi sebebiyle kelime hazinesi bakımından birbirine yaklaşırken Müslüman sahada varlığını gösteren Memluk Kıpçak Türkçesinden ayrlırlar (Argunşah-Yüksekkaya-Tabaklar 2010:175). Bu nedenle Kıpçak Türkçesi eserleri, Karadeniz’in kuzeyinde yazılmış Kuzey Kıpçak Türkçesi eserleri ile Mısır ve Suriye'de meydana getirilmiş Memluk Kıpçak Türkçesi eserleri olmak üzere iki grupta ele alınır. Memluk sahasında Kıpçak Türkçesi ile yazılmış eserler ise sözlük ve gramer kitapları ile edebî, ilmî, dinî ve askerî eserlerden oluşan eserlerdir. Hem Kuzey Kıpçak Türkçesi ile hem de Güney Kıpçak Türkçesi ile yazılmış eserlere baktı̆̆ımızda bu dönemlere ait pek çok dil malzemesine erişebilmekteyiz. Bunlardan biri de coğrafi terimlerdir ve bu terimler incelendiğinde bizlere Kıpçak Türkçesinin konuşulduğu sahalardaki yer şekilleri hakkında sağlam bilgiler vermektedir. Bu çalışmada Kıpçak Türkçesi eserleriyle tanıklanan coğrafya terimleri orman, dağ ve tepe kavram alanlarına giren terimler olmak üzere üç bölümde incelenecektir. ${ }^{2}$

Bu çalışmanın örneklem alanını tarihî Kıpçak Türkçesi ile yazılmış kaynaklar oluşturmaktadır. Bir makale olarak planlanan bu çalışmanın sınırları sebebiyle malzeme olarak yalnızca coğrafya terimleri içinden orman, dağ, tepe kavram alanlarına ait olan terimler ele alınmıştır; ancak elbet bu sahada burada incelenen terimler dışında farklı kavram alanlarına ait pek çok coğrafi terim bulunmaktadır. 


\section{Ormanlar}

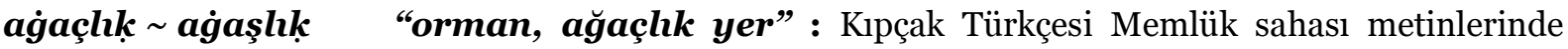

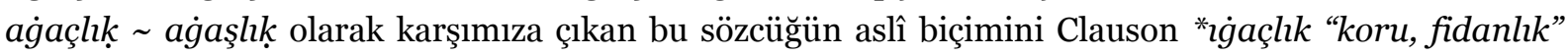
olarak verir (Clauson 1972 :80a).

Clauson ı่̇aç' in kökünü ı'ya dayandırmış ve $\imath$ maddesinde açıklama olarak bu kelimenin genellikle bitki örtüsü anlamında çevrildiğini; fakat bağlamlara göre daha çok bitki ile ağaç arasında çalıya benzer bir anlamda kullanıldığını söylemiştir (Clauson 1972: 1a; ayrıca aynı anlamlarla krş. $i$ “растение 'bitki”" Nadalyaev vd 1969:216a) ; y “gewächs 'bitki', wald 'orman”" Räsänen 1969:164a).

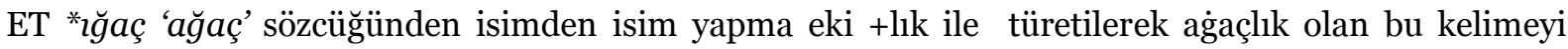
Marcel Erdal Old Turkic Word Formation adlı eserinde kelimeyi gaç küçültme eki ile 1+gaç olarak vermiş ve bu kelimenin 1 'dan türediği konusunda bir şüphe olmadığını belirtmiştir (Erdal 1991: 84). Bu terim Divanü Lûgat-it-Türk’te yıg்açhig "ağaçlık” ( Atalay 2006 : III /151 ) olarak karşımıza çıkar. Memlük Kıpçak sahası eserlerinden Ed-Dürretü'l-Mudiyye Fi'l-Lügati’t-Türkiyye 'de aġaşlık "ağaçlık" (Toparlı 2018: 13) biçimiyle; İrşâdü’l -Mûlük Ve's-Selâtîn'de ise aġaçlık “ağaçlık” biçimiyle görülmektedir: Ve eger anı ḳamışhig ḳlsa yā ağaçlık ḳılsa yā ot bitmek üçün ḳılsa anı刀 içinde öşs vācib bolur (Toparlı 1992: 255b).

Kipçak sahasında yalnızca bu iki eserde gördüğümüz kelime bugün Türkiye Türkçesinde de $a \breve{g} a c ̧ l k$ “ağacı bol olan yer” (BTS 2005: 30a ) anlamında kullanılmaktadır.

bök “orman, birbirine girmiş çah ve çırpı gibi ağaçlar” : Kıpçak Türkçesi eserlerinden yalnızca Kitâbü'l İdrâk Li-Lisâni'l- Etrâk'ta (Caferoğlu 1931: 21) karşımıza çıkan bu terimi Clauson bük başlı̆̆ altında 'slk çalılık, ağaçllk $v b$ ' anlamıyla vermiş ve bugün Kuzeydoğu grubu Türk lehçelerinde bük/ pük şekilleriyle kullanımda olduğunu belirtmiştir (Clauson 1972: 324a; ayrıca aynı anlamlarla krş. bük I "лес 'orman', чащца 'çalıllk”" Nadalyaev vd. 1969: 131b ; *bük “wald 'orman”"Räsänen 1969: 191b; bük "su kenarında sık çalılı" Tietze 2002: 404a).

Kaşgarlı bu sözcüğü bük "çalılık; çalı çırpı" anlamlarıyla vermiştir (Atalay 2006: I /333). Bugün Türkiye Türkçesinde ağızlarda varlığını sürdüren kelime, bük, buk "sık çalılık, ağaçllk"; "bodur ağaçlardan oluşan alan"; "dere kenarlarındaki sazlık"; "çalılı, sazlık ve ormanların en sık olduğu yer"; "ova ve dere kıyılarındaki çalı ve diken topluluğu" gibi anlamlarla karşımıza çıkmaktadır ( bük I DS 2019: I /814b).

\section{Dağlar}

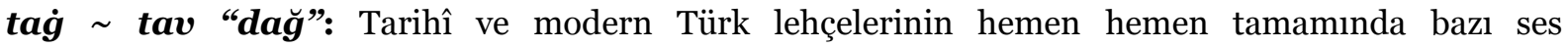

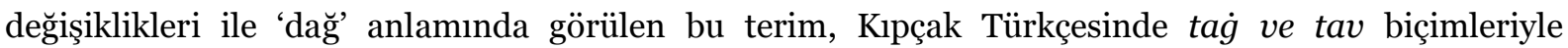
karşımıza çıkar. Clauson kelimenin Kuman Kıpçakçasında tag tav şekilleriyle ; Memlük sahası eserlerinde ise ta: $\dot{g}$, ța $\dot{g}$ ve taw şekilleriyle bulunduğunu söyler (Clauson 1972: 463a; ayrıca aynı

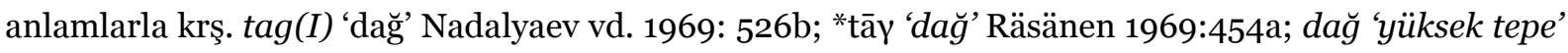
Tietze 2002: 545a).

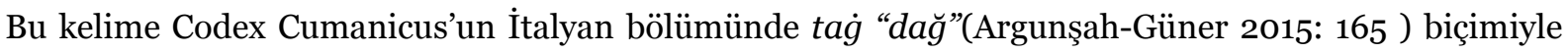
geçerken Alman bölümünde ise tav "dă̆" olarak geçmektedir: tav üstinde talaşman, tayaġı bar bèş batman (Argunşah-Güner 2015: 343).

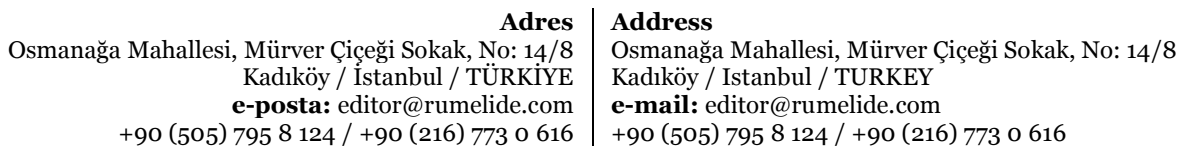




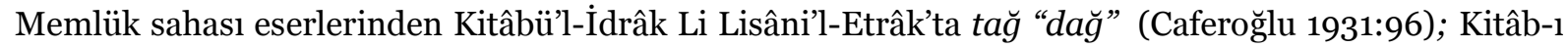
Mecmû-ı Tercümân-ı Türkî Ve Acemî Ve Mugalî̀de tag “dağ”(Toparlı vd. 2000:141); Et-Tuhfetü’zZekiyye Fil-Lügat'it-Türkiyye'de tad “dăg” (Atalay 1945:249a) tav “dă̆”(Atalay 1945: 253b); ElKavâninü'l-Külliye Li-Zabti'l-Lügati't-Türkiyye'de tag “dağ” ( Toparlı 1999: 124) tav “dă̆” ( Toparlı 1999: 125); Kitâbu Bulgatü'l-Müsşâk Fî Lügati't-Türk Ve'l-Kıfçâk’’ta țag “dă̆” (Al-Turk 2012:53 [Zajacskowski 1958: 49] ); Ed Dürretü’l-Mudiyye Fi'l-Lügati't-Türkiyye'de țag “dağ”(Toparlı 2018: 110); İrşâdü'l-Mülûk Ve's-Selâtin'de țag் “dağ” olarak geçer: Müderrec-i 'Oșmān birle anda iski ḳuyug bar, 'Oşmān ḳuyusı dirler taḳı kal'a bar taġ öze (Toparlı 1992: 302a).

Kelime bugün Türkiye Türkçesinde dă̆ "yer kabuğunun çıkıntılı, yüksek, eğimli yamaçları ile çevresine hakim ve oldukça geniş bir alana yayılan bölümü” olarak geçmektedir ( BTS 2005: 458a).

yaka “ dağın kenarı, bayır olan yeri” : yaka sözcüğü bir coğrafî terim olarak yalnızca El-İdrâk Haşiyesi’nde "dağın kenarı, bayır olan yeri" anlamında geçer ( İzbudak 1936: 50). Clauson yaka maddesinde bu kelimenin temel olarak bir şeyin kenarı, kıyısı anlamlarında var olan bir sözcük olduğunu belirtmiştir (Clauson 1972: 898a; ayrıca aynı anlamlarla krş. jaka "ufer 'kıyı'; rand 'kenar' " Räsänen 1969:180a).

Bugün bu kelime Anadolu ağızlarında da kıyı; sırt, bayır anlamlarıyla varlığını sürdürmektedir (DS VI 2019: 4129).

\section{Tepeler}

depe $\sim$ tebe $\sim$ tepe $\sim$ töpe $\sim$ tüpe "tepe" : Kıpçak Türkçesi metinlerinde depe, tebe, tepe, töpe şekilleriyle karşımıza çıkan bu sözcüğü Clauson töpü (töpö) maddesinde the top 'zirve, doruk' anlamını vermiş ve daha çok doğa özelliği (dağ vs) veya insan başı için kullanıldığını; dolayısıyla genişlemeyle 'tepe' anlamına geldiğini söylemiştir (Clauson 1972: 436a; ayrıca aynı anlamlarla krş töрӥ “вершина 'tepe" ” Nadalyaev vd. 1969: 580a ; töpä “gipfel 'zirve', scheitel 'tepe” Räsänen 1969: 494a).

Divanü Lûgat-it-Türk'te tüpü "tepe" (Atalay 2006: III / 216) maddesinde verilen bu kelime Codex Cumanicus'ta tèbe "başın üst kısmı, başın tepesi" (Argunşah-Güner 2015: 569); Kitâbü'l-İdrâk'te täpä "tepe" (Caferoğlu 1931: 101); Kitâb-1 Mecmû-ı Tercümân-1 Türkî'de tepe "tepe" (Toparlı vd. 2000:144); Et-Tuhfetü'z-Zekiyye'de depe tüpe "tepe"(Atalay 1945: 164b; 267a); Ed- Dürretü'lMudiyye'de tepe "tepe, yığın,toprak tepe" (Toparlı 2018:113); Bulgatü'l-Müştâk’ta töpe "tepe" (Al-Turk 2012:63 [Zajacskowski 1958: 52] ); Baytaratu'l-Vâzıh'ta töpe "tepe" : bolgay takı atnı töpesindeki süyüki belgüsiz (Ağar 1986: 5b 24); İrşâdü’l-Mülûk'te töpe "tepe": 'Uyūn-ı Mūsānnı șlfatı kim ol, bir töpe turur yüksek büyük yirni kazsa suf tapllur, aşak yirni ḳazsa suf tapulmas.

Kelimenin Codex Cumanicus ve Baytaratu'l-Vâzıh'taki örneklerine baktığımızda yalnızca "başın üst tarafı" anlamında geçtiğini görmekteyiz. Bununla ilgili olarak Doerfer Türkische und Mongolische Elemente im Neupersischen adlı eserinde, bu kelimenin "tepe, başın üst kısmı, zirve" anlamlarında olduğunu söyler ve bazen sadece Codex Cumanicus'ta olduğu gibi "başın üst kısmı" anlamında, bazen de sadece coğrafi terim olan tepe anlamında kullanıldığını belirtir. Doerfer bundan dolayı zirve, yükseklik anlamındaki "tepe" ile coğrafi terim olan "tepe" arasında bir ayrım yapmanın çok zor olduğunu söylemiş̧tir ( Doerfer 1965: II /450).

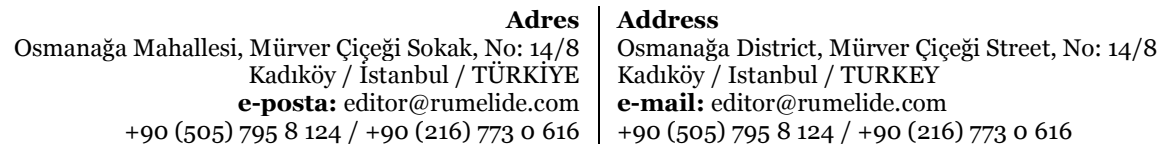


Eski Türkçe döneminden itibaren tarihî lehçelerin tamamında görülen ve bugün de modern Türk lehçelerinde varlığını sürdüren bu kelime Türkiye Türkçesi ağızlarında depe, deppe "tepe, baş, uç" anlamlarında kullanılmaktadır (DS II 2019: 1426).

doru "tepe, en yüksek yer, doruk" : Eski Türkçe dönemi metinlerinde karşımıza çıkmayan bu kelime Kupçak dönemi eserlerinden El-İdrâk Haşiyesi’nde geçer (İzbudak 1936: 16) . Bu kelimeyi Hasan Eren doruk maddesinde doruk < toruk “ dă̆, ulu ağaç gibi yüksek şeylerin tepesi, en yüksek yeri, zirve” olarak verir ve kökeninin bilinmediğini söyler. Eren ayrıca bu kelimenin eski kaynaklarda toru, tora biçimlerinde de geçtiğini belirtmiştir (Eren 1999: 120a). Tuncer Gülensoy ise bu kelimenin ET tur- 'çıkmak, yükselmek' fiilinden +(u)k ekiyle türetilmiş bir isim olduğunu söylemiş ve kelimeyi Divanü Lûgat-it-Türk’te geçen turk 'bir cismin uzunluğu, boyu' kelimesi ile karşllaştırmıştır (Gülensoy 2007: 299). Andreas Tietze ise bu kelimeyi doru/ doruk "en yüksek yer, tepe, zirve" olarak vermiştir (Tietze 2002: 647a).

Bugün bu kelime Türkiye Türkçesinde "dağ, ağaç vb. yüksek şeylerin tepesi, en yüksek yeri, zirve, şahika” ( BTS 2006: 561) anlamlarında geçerken Anadolu ağızlarında da dora, dorak, doran, doru, dorug, doruh, dörük, duruk biçimleriyle "tepe, en yüksek yer, uç" anlamlarında görülmektedir (DS II 2019: 1564b).

kaş “tepenin başı” : Kitâbü'l- İdrâk Li Lisâni'l-Etrâk'ta tepenin başı (Caferoğlu 1931:72) anlamıyla geçen bu kelimeyi Clauson sözlügünde ka:ş maddesinde herhangi bir şeyin kenarı, kıyısı; tepesi, doruk noktası anlamlarında vermiştir ( Clauson 1972:669b ; ayrıca aynı anlamlarla krş. kāt "hügel" Räsänen 1969: 240a ; kaş III “бровка” Nadalyaev vd.1969: 431a).

Bu terim Kıpçak Türkçesinde Kitâbü'l- İdrâk Li Lisâni'l-Etrâk dışında herhangi bir yerde karşımıza bu anlamıyla çıkmaz. Tarihî sahada coğrafi terim olarak daha çok "herhangi bir şeyin kenarı, kıyısı" anlamlarında karşılaştığımız kelimeyi Kaşgarlı da sözlüğünde "herhangi bir şeyin kıyısı" anlamında vermiştir (Atalay 2006: III/152). Bugün ise bu kelimenin Türkiye Türkçesi ağızlarında "tepe, dă̆" anlamlarıyla kullanımda olduğu yerler olduğunu görmekteyiz (DS IV 2019: 2678a).

kayır kuyır “ kum tepesi, dalgah kumdan meydana gelmiş olan tepecikler” : EtTuhfetü'z-Zekiyye Fil-Lügat'it-Türkiyye'de karşımıza çıkan ( Atalay1945: 189a) bu terim Kıpçak sahasında daha çok küçük çakıl, kum anlamlarında kullanılan bir kelimedir. Clauson kelimenin anlamını verirken Tuva Türkçesinde kayr/kayır/xayır şekilleriyle "çorak bozkır ya da dağlardaki bataklık” anlamlarında kullanıldığını, Kazak, Karakalpak, Nogay ve Osmanlı Türkçelerinde ise kayır "karada ya da su alanlarındaki kumluk alan, kumların oluşturduğu birikinti” olarak varlığını sürdüren bir kelime olduğunu söylemiştir (Caluson 1972:678b; ayrıca aynı anlamlarla krş: kajyr Räsänen 1969: 221b; qajï I песок Nadalyaev vd. 1969 : 407b).

Kaşgarlı Divanü Lûgat-it-Türk’te kayır maddesinde “Türklerce kaba topraklı yer” açıklamasını yapmış ve Oğuzların kuma kayır dediklerini söylemiştir ( Atalay 2006: III / 165). Kelime bugün Türkiye Türkçesi ağızlarında kayır "kalın kum, ince kum, taşlı toprak, tabaka tabaka olan sert ve sarı toprak, verimsiz toprak, çakıl taşı, iri taş, dama serilen killi toprak" anlamlarında ve kıyır "kumlu toprak" anlamında kullanılmaktadır (DS 2019: IV/2701).

keriş “tepe": Kıpçak Türkçesi eserlerinden Kitâbü'l- İdrâk Li Lisâni'l-Etrâk'ta tepe (Caferoğlu 1931:45) anlamıla geçen bu kelimeyi Clauson sözlüğünde the summit of any mountain that is

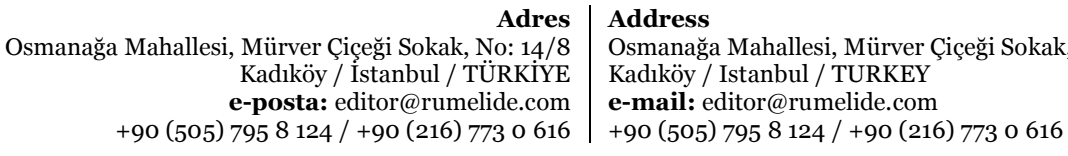


climbed "tırmanılan herhangi bir dağın zirvesi" olarak vermiştir ve kelimenin ker- "birbirini çek-" kökünden geldiğini söylemiştir ( Clauson 1972: 747a ; ayrıca aynı anlamlarla krş. käriț "berggipfel ‘dağ zirvesi”’ Räsänen 1969:256b ; keriş (I) Nadalyaev vd. 1969 : 301a).

Sözcük bu anlamıyla Divanü Lûgat-it-Türk’te de geçer : keriş “üstüne çıkılabilen dağ tepesi” ( Atalay 2006: I /370). Bugün bu kelime Türkiye Türkçesi ağızlarında da yokuş, tepe anlamlarında karşımıza çıkmaktadır ( DS IV 2019: 2755b).

kar “tepe başı” : Kitâbü’l- İdrâk Li Lisâni'l-Etrâk'ta tepe başı (Caferoğlu 1931:76) anlamıyla karşımıza çıan bu kelime için Clauson an isolated mountain or block of mountains "ayrı bir dă̆ veya dağ kütlesi” anlamını vermiş, bu anlamda ve daha çok yüksek yer anlamında hemen hemen bütün modern Türk lehçelerinde var olan bir kelime olduğunu belirtmiştir. Clauson aynı zamanda bu kelimenin, Kuzeybatı grubu lehçelerinden Nogay Türkçesinde ve Güneybatı grubu lehçelerinden Osmanlı Türkçesinde daha çok ova, bozkır, çöl anlamlarında kullanıldığını söylemiştir (Clauson 1972:641a; ayrıca aynı anlamlarla krş. kyr “berg ‘dă̆’, bergrücken 'çıkntı’” Räsänen 1969:265b).

Kıpçak sahasında bu anlamda başka yerde görülmeyen bu kelimenin Divanü Lûgat-it-Türk'te de "basık dağ” anlamıyla karşımıza çıktığını görüyoruz (Atalay 2006: I /324). Bugün bu kelimenin Türkiye Türkçesinde ve Anadolu ağızlarında bu anlamda bir kullanımına rastlamamaktayız. Kelime Türkiye Türkçesinde "Şehir ve kasabaların dışında kalan çoğu boş ve geniş yer, dağ bayır" anlamıyla kullanılmaktadır (BTS 2005:1157a).

örleş “tepe, yokuş": Codex Cumanicus'ta “tepe” anlamında (Argunşah-Güner 2015: 538 ); İrşâdü’l -Mûlük’te ise "yokuş" anlamında (Toparlı 1992: 41a) geçen bu kelimeye tarihî sahada ilk kez bu metinlerde rastllyoruz. Kelimenin ör "yükseklik" isim kökünden mi yoksa ör-“ belirmek, çıkmak, yükselmek" fiilinden mi türediğini bilmiyoruz. Clauson ör maddesinde "yükseklik, yüksek, yüksek zemin" anlamlarını vererek bunun ör- "belirmek, çıkmak, yükselmek, filizlenmek" fiili ile eş sesli olduğunu; fakat çağrıştırdığı anlamların biraz farklı olmasından dolayı muhtemelen birbirleri ile ilişkili olmadıklarını belirtmiştir. Ayrıca ör ismine Orta Türkçe döneminden önce rastlanmadığını; ancak örle:- "yükselmek, belirmek, çımak" ve örlet-"yükselmek" fiillerinin köklerinin buradan geldiği için daha eski bir kelime olduğunu da belirtmiştir (Clauson 1972:193a; ayrıca aynı anlamlarla krş. ör “ eine hohe stelle, erhöhung 'yüksek bir yer, tepe" , *ör: "aufsteigen 'yüksel-" Räsänen 1969: 373b; ör- I “показываться” 'ortaya çık-' , “подниматься” 'yüksel-” Nadalyaev vd. 1969: 388a). Buna göre kelime ör "yükseklik" isim kökünden +le eki ile örle- "yükselmek" şeklinde türemiş ve örle- fiiline getirilen -ş eki ile örleş "tepe, yokuş" anlamlarını kazanmış olmalı.

Marcel Erdal ise örle- "yükselmek” fiilini ör-“ belirmek, çlkmak, yükselmek” fiilinden türeyen örü "yüksek, dik, üst" ismine +lä isimden fiil yapma eki getirilerek oluşturulduğunu söylemiştir ( Erdal 1991: 443). Bu durumda Marcel Erdal kelimenin kökünü ör- fiiline dayandırmıştır.

Kelimenin tarihî sahada başka yerde "tepe" anlamına rastlanmazken Çağatay Türkçesinde ör / örk biçimiyle "yokuş, yukarı" (Clauson 1972:193a) anlamlarında ve örle- biçimiyle "yokuşla-, yokuşa çık-" (Clauson 1972: 230a) anlamlarında kullanıldığı görülmektedir. Bugün Türkiye Türkçesi ağızlarında ise örle- "yokuşu koşarak çıkmak" şeklinde bir kullanım vardır ( DS 2019: V/335ob).

senir “tepe” : Kelime Kıpçak sahasında yalnızca Kitâbü'l- İdrâk Li Lisâni'l-Etrâk'ta tepe (Caferoğlu 1931:89) anlamı ile geçer. Clauson bu sözcüğü "bir dağın (yatay veya dikey) çıkk kısmı; dolayısıyla

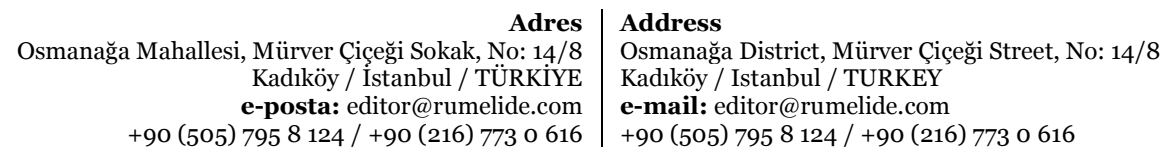


da bir duvarın (köşe veya destek) çıkı kısmı” olarak vermiştir (Clauson 1972: 840b; ayrıca aynı anlamlarla krş. säyir “vorgebirge’burun”, "berg vorsprung 'dağ çlkıntısı” Räsänen 1969: 410a ; säyir Nadalyaev vd. 1969: 495b).

Kelime Divanü Lûgat-it-Türk’te segir “dă̆ çıkıntısı, dağ burnu, herhangi bir duvarın ucu” anlamıyla geçer (Atalay 2006: III/ 362). Türkiye Türkçesi ağızlarında ise bu kelimenin "iki dağ arasındaki sırt; yükseklik; tepe, doruk; dağın vadiye bakan yamacı” anlamlarıla kullanılmakta olduğunu görüyoruz (DS 2019:V/ 3584a).

sırt "sırt, tepe, yükseklik" : Bu kelime Kıpçak sahası eserlerinden Bulgatü’l-Müştâk’ł'ta sırt "dağlartn ve tepelerin üst bölümü” (Al-Turk 2012:63 [Zajacskowski 1958: 52] ) anlamında geçerken Kitâbü'l- İdrâk'ta sirt "yüksek arazi" (Caferoğlu 1931: 91); Codex Cumanicus'ta ise sirt "tepe, sirt" anlamlarında (Argunşah-Güner 2015: 814) geçer.

Clauson bu kelimenin çeşitli alanlarda farklı anlamlara sahip olduğunu söylemiş ve kelimeyi açıklarken a mountain ridge "dă̆ çıkıntısı" anlamını da vermiştir (Clauson 1972: 846a; ayrıca aynı anlamlarla krş. syrt "erhöhüngen 'tepe,dağ"” Räsänen 1969: 419b; sïrt I возвышенност "yükseklik" Nadalyaev vd. 1969: 505b).

Kaşgarlı Divanü Lûgat-it-Türk'te "Oğuzlar bayır ve yokuş gibi yerlere ve küçük derelere dahi sırt derler" demiştir ( Atalay 2006: I / 342). Bugün bu kelime Türkiye Türkçesinde de “dağlarn ve tepelerin üst bölümü” anlamında varlığını sürdürmektedir ( BTS 2006: 1759).

üyük "büyük tepe, höyük": Kelime Bulgatü'l-Müştâk’ta üyük “ yığma toprak tepe, höyük”(AlTurk 2012:63 [Zajacskowski 1958: 63] ) olarak; Kitâbü'l- İdrâk'ta ise üyük "büyük tepe” (Caferoğlu 1931: 116) olarak geçer.

Clauson bu kelimeyi öyük maddesinde vermiş ve eş sesli görünen iki ayrı öyük sözcüğünün varlığından bahsetmiştir. Bunlardan birisinin öyük- fiili ile ilgili olduğu ve vokalinin belirsiz olduğunu söyleyerek ikincisinin ise Oğuzların şu an kullandığı öyük ismi olduğunu belirtmiş ve öyük 2 maddesinde "yapay höyük, tümülüs vb." anlamlarını vermiştir ( Clauson 1972: 271; ayrıca aynı anlamlarla krş.üjük "hügel ‘tepe” Räsänen 1969: 519a; üjük II “холм 'tepe”” Nadalyaev vd. 1969: 623b).

Kelimenin Divanü Lûgat-it-Türk’te “tepe gibi yüksek olan yerler” anlamı vardır (Atalay 2006: I/ 85). Bugün Türkiye Türkçesinde höyük "toprak yığınl, küçük tepe" (BTS 2006: 902b) anlamını sürdüren bu kelimenin Anadolu ağızlarında ise üyük "büyük, yığma toprak tepe" şekliyle kullanımda olduğunu görüyoruz ( DS 2019: VI/ 4086a). 
Tablo 1'de Kıpçak Türkçesinde tespit edilen terimlerin Türkiye Türkçesindeki karşlıkları verilmiştir.

Tablo 1. Kıpçak Türkçesinde bulunan orman, dă̆, tepe kavram alanlarına ait terimlerin Türkiye Türkçesindeki kullanım durumu.

\begin{tabular}{|c|c|}
\hline KIPÇAK TÜRKÇESİ & TÜRKİYE TÜRKÇESİ \\
\hline $\begin{array}{l}\text { ag̉açlık ag̉aşlık :Orman, } \\
\text { ağaçlık }\end{array}$ & ağaçlık: Ăgacı bol olan yer (BTS) \\
\hline $\begin{array}{l}\text { bök: Orman, birbirine girmiş çalı } \\
\text { ve çırpı gibi ağaçlar. }\end{array}$ & $\begin{array}{l}\text { bük I : 1.Sık çalılık, ağaçlık. 2. Bodur ağaçlardan oluşan alan. 3.Dere } \\
\text { kenarlarındaki sazlık. 4. CCalılık, sazlık ve ormanların en sık olduğu yer. } \\
\text { 5.Ova ve dere kıylarındaki çalı ve diken topluluğu (DS) }\end{array}$ \\
\hline $\operatorname{tag} \sim \operatorname{tav}:$ Dağ & dağ: Dağ (BTS) \\
\hline $\begin{array}{l}\text { yaka: Dağın kenarı, bayır olan } \\
\text { yeri. }\end{array}$ & yaka I: 1. Kıyı 2. Sirt, bayır (DS). \\
\hline $\begin{array}{l}\text { depe } \sim \text { tebe } \sim \text { tepe } \sim \text { töpe } \sim \\
\text { tüpe : Tepe. }\end{array}$ & depe, deppe Tepe, baş, uç (DS) \\
\hline $\begin{array}{l}\text { doru : Tepe, en yüksek yer, } \\
\text { doruk. }\end{array}$ & $\begin{array}{l}\text { doruk: Dağ, ağaç vb. yüksek şeylerin tepesi, en yüksek yeri, zirve, şahika ( } \\
\text { BTS ). } \\
\text { dora, dorak, doran, doru, dorug, doruh, dörük, duruk: Tepe, en } \\
\text { yüksek yer, uç (DS) }\end{array}$ \\
\hline kaş: tepenin başı. & kaş: Tepe, dağ (DS) \\
\hline $\begin{array}{l}\text { kayır kıyır : Kum tepesi, } \\
\text { dalgalı kumdan meydana gelmiş } \\
\text { olan tepecikler. }\end{array}$ & $\begin{array}{l}\text { kayır : Kalın kum, ince kum, taşlı toprak, tabaka tabaka olan sert ve sarı } \\
\text { toprak, verimsiz toprak, çakıl taşı, iri taş, dama serilen killi toprak (DS). } \\
\text { kıyır: Kumlu toprak (DS). }\end{array}$ \\
\hline keriş: Tepe & keriş: Yokuş, tepe (DS). \\
\hline ḳır : Tepe başı & - \\
\hline örleş: Tepe, yokuş. & - \\
\hline senir : Tepe. & $\begin{array}{l}\text { senir: } 1 . \dot{I} k i \text { dağ arasındaki sırt. 2. Yükseklik. 3. Tepe, doruk. 4.Dağın vadiye } \\
\text { bakan yamacı (DS). }\end{array}$ \\
\hline sırt : Sirt, tepe, yükseklik. & sırt: Dağların ve tepelerin üst bölümü (BTS). \\
\hline üyük: Büyük tepe, höyük. & üyük :büyük, yığma toprak tepe (DS). \\
\hline
\end{tabular}

\section{Sonuç}

Kıpçak Türkçesinden bugüne kalan dil yadigârlarını incelediğimizde Kıpçak Türklerinin yaşadığı coğrafyaya ve Kıpçak Türkçesinin kullanıldığı sahaların yaşam alanına dair sağlam dil verileri elde etmekteyiz. Bir milletin içinde bulunduğu coğrafyanın özelliklerinin o milletin dil hazinesine yansıdığı yadsınamaz bir gerçektir. Bu bağlamda bu çalışmada Kıpçak Türkçesi eserlerinden tanıklanan coğrafi terimler içinden ele alınan orman, dă̆, tepe kavram alanlarına ait olan terimler de bizlere yaşanılan coğrafya hakkında bazı ipuçları vermektedir.

Bu çalışmada Kıpçak sahası eserlerinde yer alan orman, dağ ve tepe ile ilgili terimler ele alınmış ve yapılan tarama sonucunda ag̉açlık $\sim$ ag̉aşlık, bök, tag $\sim$ tav, yaka, depe $\sim$ tebe $\sim$ tepe $\sim$ töpe $\sim$ tüpe, doru, kaş, kayır kııır, keriş, kır, örleş, senir, sırt, üyük kelimeleri tespit edilmiştir. Daha sonra tespit edilen bu coğrafi terimler etimolojik olarak incelenerek tarihî süreç içerisindeki durumları ve varsa Türkiye Türkçesindeki kullanımları ortaya konmaya çalışılmıştır. Çalışmanın sonunda ise ilgili sözcüklerin Kıpçak Türkçesindeki ve Türkiye Türkçesindeki kullanım durumlarını gösteren bir tablo verilmiştir. 
Çalışmada ele alınan terimlerden bök, yaka, doru, kaş, kayır kıyır, keriş, kır, senir kelimeleri yalnızca tek eserde geçerken agacçlı $\sim$ aġaşlı̣, tag $\sim$ tav , depe $\sim$ tebe $\sim$ tepe $\sim$ töpe $\sim$ tüpe, örleş, sırt, üyük kelimelerinin birden fazla eserde geçtiği görülmüştür. Sonuç olarak ele alınan terimlerden aġaçlık ag̉aşlık, bök, tag $\sim$ tav, yaka, depe $\sim$ tebe $\sim$ tepe $\sim$ töpe $\sim$ tüpe, doru, kaş, kayır $\sim$ ḳıır, keriş, senir, sırt, üyük kelimelerinin bazı fonetik farklılıklarla bugün Türkiye Türkçesinde ve Anadolu ağızlarında aynı anlamlarla yaygın biçimde kullanıldığı gözlemlenmiştir. Ele alınan terimlerden ḳır kelimesinin bugün Türkiye Türkçesinde Kıpçak Türkçesindeki "tepe başı" anlamından çok başka bir anlamla, "Şehir ve kasabaların dışında kalan çoğu boş ve geniş yer, dağ bayır " anlamıyla kullanılmakta olan bir kelime olduğu görülmüş; örleş "tepe, yokuş" sözcügünün ise Türkiye Türkçesinde herhangi bir karşılığı bulunmamakla birlikte Anadolu ağızlarında örle- "yokuşu koşarak çıkmak" fiilinin kullanımda olduğu gözlemlenmiştir.

\section{Kisaltmalar}

BTS: Büyük Türkçe Sözlük

DS: Derleme Sözlüğü

Krş: Karşılaştırınız

\section{Kaynakça}

Al-Turk, G. (2012). Kitābu Bulgatü'l-Müştak fî Lugati't-Türk ve’l-Kıfçak Üzerine Dil

İncelemesi. Gazi Üniversitesi Sosyal Bilimler Enstitüsü, Türk Dili ve Edebiyatı Ana Bilim Dalı, Yayımlanmamış Doktora Tezi. Ankara

Argunșah, M.; Yüksekkaya, G.; Tabaklar, Ö.( 2010). Karahanlıca Harezmce Kıpçakça Dersleri. Istanbul: Kesit Yayınları.

Argunşah,M.; Güner, G.(2015). Codex Cumanicus. İstanbul: Kesit Yayınları.

Atalay, B. (2006). Divanü Lûgat-it-Türk I-IV. Ankara: Türk Dil Kurumu.

Atalay.B. (1945). Et-Tuhfetü'z-Zekiyye Fil-Lügat’it-Türkiyye. İstanbul: Türk Dil Kurumu.

Büyük Türkçe Sözlük (2005).Ankara: Türk Dil Kurumu.

Caferoğlu, A.(1931). Kitâb al-İdrâk li-lisân al-Atrâk. İstanbul: Evkaf Matbaası.

Clauson, G. (1972). An Etymological Dictionary of Pre-thirteenth-Century Turkish. Oxford: The Clarendon Press.

Derleme Sözlüğü I-VI (2019). Ankara: Türk Dil Kurumu.

Doerfer, G.(1965). Türkische Und Mongolische Elemente İm Neupersischen. 2.Türkische Elemente imNeupersischen: alif bis tā . Wiesbaden: Akademieder Wissenschaften und der Literatur [Mainz]. Veröffentlichungen derOrientalischen Kommission.

Erdal, M (1991). Old Turkic Word Formation. A Functional Approach to the Lexicon, Vol. I-II, Wiesbaden: Harrassowitz.

Gabain, A. V. (2003). Eski Türkçenin Grameri. Ankara: Türk Dil Kurumu.

İzbudak, V.(1936). El-İdrâk Haşiyesi. İstanbul: Devlet Basımevi.

Nadalyaev V. M.; Nasılov, D. M.; Tenişev, E. R. ; Şçerbak, A. M.. (1969). Drevnetyurkskiy Slovar', Leningrad: Izdat. Nauka, Leningradskoe Otd. (Akademiya Nauk SSSR. Institut Yazıkoznaniya)

Räsänen M. (1969). Versuch Eines Etymologischen Wörterbuchs der Türksprachen, Helsinki: Lexica Societatis Fenno-Ugricae: 17, 1.

Tekin, T.; Ölmez, M. (1999). Türk Dillleri Giriş. İstanbul: Simurg.

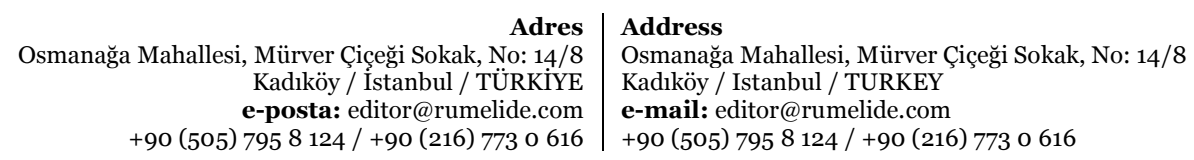


Tıetze, A. (2002). Tarihi ve Etimolojik Türkiye Türkçesi Lugati. Sprachgeschichtliches und etymologisches Wörterbuch des Türkei Türkischen, Birinci cilt A-E, İstanbul-Wien: Simurg

Toparl, R.(2018). Ed Dürretü’l-Mudiyye Fi'l-Lügati’t-Türkiyye. Ankara: Türk Dil Kurumu.

Toparlı, R.; Çögenli, M.S.; Yanık, N.H. (1999). El-Kavâninü'l-Külliye Li-Zabti'l-Lügati't-Türkiyye. Ankara: Türk Dil Kurumu.

Toparl, R.( 1992). İrşâdü’l-Mülûk Ve's-Selâtin. Ankara: Türk Dil Kurumu.

Toparlı, R.; Vural, H. ve Karaatlı, R. (2007). Kıpçak Türkçesi Sözlüğü. Ankara: Türk Dil Kurumu.

Toparlı, R.; Çögenli, M.S.; Yanık, N. H. (2000). Kitâb-ı Mecmû-ı Tercümân-ı Türkî Ve Acemî Ve Mugalî. Ankara: Türk Dil Kurumu.

Ünlü, S. (2012). Karahanlı Türkçesi Sözlüğü. Konya: Eğitim. 